\title{
A Poggean Reform Agenda for Improving Political Will in Response to Mass Atrocities
}

\author{
JED LEA-HENRY
}

$\frac{\text { DE }}{\mathrm{G}} \stackrel{\text { DE GRUYTER }}{\text { OPEN }}$

Politics in Central Europe (ISSN: 1801-3422)

Vol. 14, No. 1

DOI: 10.2478/pce-2018-0005

\begin{abstract}
Like other types of humanitarian intervention before it, the Responsibility to Protect (R2P) has suffered in practice from a pervasive lack of political will. This represents a failure of moral motivation, but also a failure to accept the often steep political, material and human costs associated with intervening to try and halt mass atrocity crimes. In order to ease this second barrier to intervention, we need a reform agenda that will limit the prevalence, intensity and duration of mass atrocities as well as the crisis situations that make them possible, thereby reducing the various costs associated with any specific intervention. This can be achieved through certain aspects of the work of cosmopolitan philosopher Thomas Pogge.
\end{abstract}

Keywords: Responsibility to Protect, R2P, Thomas Pogge, mass atrocities, humanitarian intervention

\section{Introduction: The Need for a Reform Agenda}

"Intervention is no substitute for prevention" - Alan Kuperman

The Responsibility to Protect (R2P), like other kinds of humanitarian intervention before it, has failed in practice despite the best hopes of many international actors and supranational institutions. The failure comes down to a simple lack of political will to take action (Lea-Henry 2014: Ch. 1). The political, material and human costs associated with intervention have effectively become a near permanent barrier to fulfilling our moral obligations associated with mass atrocities. This is despite the fact that in most mass atrocity crimes, the vast majority of the world's citizens can be proven to have an institutional responsibility and 
hence a moral obligation to remedy the violence in question (Lea-Henry 2014: Ch. 2). Furthermore, this institutional responsibility gives rise to a secondary obligation to "compensate" by way of reforms intended to avoid such violence in the future (Pogge 2008: 26).

This situation calls for the creation of a reform agenda which can limit the prevalence, intensity and duration of mass atrocities and the crisis situations that make them possible, thereby reducing the various costs associated with and, thus, also the barriers to - any future interventions. The less violence there is in the world, the more likely people are to be morally outraged enough to confront it when it occurs. These changes can be achieved through certain aspects of the work of the cosmopolitan philosopher Thomas Pogge.

The links between mass atrocities and potential causal factors are always complex (Bellamy 2011b) and the global institutional order that is the focus of much of Pogge's work can be shown to be manifestly unjust in countless possible ways. As such, there are literally tens of thousands of possible reforms that would produce progress in this regard, making the process of global justice-seeking reform one that is neither special nor particularly creative (Pogge 2008: 18). This has led to a failure to focus in the international community, which by and large has pursued uniform reform agendas that value the current hierarchy. The international order and its unjust nature are, however, neither accidental nor organic; rather, they have been designed to satisfy the self-interest of various global actors. For this reason, any open and far-reaching attempt to overhaul and reconstruct the international institutional order is likely to be politically unachievable. Instead what is needed is a reform agenda that is minimally imposing upfront and still manages to have a disproportionate impact downstream through intelligent targeting (Pogge 2005a: 59; Pogge 2012a; Pogge $2012 b)$. It should operate, as Pogge (2005a) notes, in much the same way that the "Manchester mobilization of 1787 triggered the defeat of slavery," that is, through an "intelligent effort by even just 11,000 people" (p. 83).

Though his work focuses predominantly on the issue of global poverty, Pogge has inadvertently produced precisely such an achievable global reform agenda that is capable of dramatically affecting the incidence of mass atrocities around the world without being too openly imposing. By operating from key indices for understanding the prevalence of (i) four kinds of crime (genocide, crimes against humanity, war crimes and ethnic cleansing) and mass atrocities and (ii) the phenomena that may potentially be their causes (poverty, inequality, environmental degradation, autocratic governments, ethnic tensions, arms flows and internal repression), a few strategically important reforms could have a disproportionately large impact by reducing the prevalence, intensity and duration of such humanitarian crises. These reforms could also increase the political will for humanitarian intervention and R2P by making such actions more palatable and their moral force all the more convincing. 


\section{Addressing the Borrowing Privilege}

"The task of building a democracy is harder than razing a dictatorship" -

William Dobson

Statistics show that almost all mass atrocity violence happens within situations of forced regime change, loss of central authority or reversal of democracy (Ulfelder 2012) and in the absence of genuine political representation (Pogge 2010: 41). The mere presence of authoritarian governments dramatically increases the likelihood of mass atrocity crimes occurring (Bellamy 2011a: 108, 97). Indeed a metadata analysis of 47 independent studies showed a strong tendency towards mass violence and internal conflict within autocratic and repressive regimes (Bellamy 2011a: 97).

Significant economic growth, itself a significant bulwark against mass atrocities, is most commonly achieved through democratic institutions (Moyo 2010; Gasiorowski - Power 1998; Huntington 1984: 198-199; Pinkney 2004: 6). Democratic Peace Theory indicates that democratic governments are less likely to go to war against one another, thereby reducing the regularity of the type of conflict zone in which the "mass slaughter of civilians" is likely to happen (Kuperman 2001: 116; Weiss 2007: 62; Russett - Layne - Spiro - Doyle 1995). Moreover democratic states are statistically more likely to participate in and support peacekeeping missions (Perkins - Neumayer 2008). Once established, democracies tend to create a cultural contagion, with the presence of regional democracies increasing the likelihood that new democracies will form, be accepted and survive in the long term (Pogge 2008: 156; Gasiorowski - Power 1998). Similarly, once a democratic form of governance has been maintained for a period over 12 years, it becomes culturally entrenched and develops institutional strength against attempted reversals (Gasiorowski - Power 1998).

Genuine democratic institutions are the best means to build "social capital" (Fukuyama 2001) and achieve key goals including establishing impartial legal structures, realising human rights, producing social equality and protecting against the state itself (Lijphart 1991; Moyo 2010; Pogge 2008: 152; Huntington 1984: 205-210). Democracies have been shown to meet the basic needs of their citizens 70 percent more effectively than non-democracies (Moyo 2010). By embracing constitutionalism, such democracies can also ease entrenched ethnic divisions (Collier et al. 2003: 57). In this respect, "[d]emocracy is a scalar predicate," producing a foundational level of protection against mass atrocity crimes (Pogge 2008: 153). And importantly for Pogge's reform agenda, both the strength of new democracies and the ability to transition to democracy depend heavily on elements of foreign policy.

For these reasons, the reform agenda developed by Pogge to address the "borrowing privilege" (a current international norm) offers a pathway away 
from coups, civil wars, conflict, violence and repressive autocratic rule and towards democratic consolidation. The borrowing privilege gives anyone who gains control over a country, no matter how this happened or how their power is maintained, the right to borrow internationally in the name of that country. Significantly, this privilege is afforded regardless of how the borrowed funds are used. This makes the borrowing privilege an extremely attractive means of personal enrichment as well as a way of holding power by force in cases where the privilege is used to arm and develop repressive internal security structures. The borrowing privilege is, thus, an incentive for carrying out mass atrocities and creating the structural environments that cause them. Institutional reform of the borrowing privilege could be achieved through intervention agreements, democratic panels and, in particular, use of a democratic fund.

Under intervention agreements, new and/or weak democratic states sign contracts with powerful organisations and states that pre-authorise intervention if the government in question is removed by coup or itself turns undemocratic (Pogge 2008: 159). Such agreements could undoubtedly help produce the desired political will for intervention by seeking it out before the need for it arises; even more importantly, this pre-emptive arrangement would rely on a select few strategically linked states and organisations. This would help bypass the requirements for achieving collective political will at the United Nations Security Council (UNSC). As open statements of joint desire and commitment, these binding bilateral agreements would also have a normative strength and legality which, though potentially challengeable, might be a significant protective mechanism and deterrent against anti-democratic shifts. Nevertheless, this approach would likely meet with a few difficulties including the reluctance of states to sign their sovereign rights over to third parties and the reality that democratic deviations and coups often appear ambiguous (Pogge 2008: 159).

Democratic panels offer a more targeted response to the problem. Under this approach, new and/or weak democratic states would adopt constitutional amendments explicitly affirming that future debts incurred under a non-democratic government would not be serviced due to their non-constitutionality (Pogge 2008: 160). These provisions should deter any future creditors from lending to the country in question while it remains non-democratic. Moreover, because of the advance public notice, there should be significant pressure on creditors not to pursue loan repayments that violate this constitutional amendment. Importantly, a credible external authority with constitutional expertise and transparent guidelines - a democratic panel - would be set up to assess the nature of the government at specific times, thereby offering clarity to the business community and international creditors (Pogge 2008: 160-161). Establishing such a panel would be a fairly simple proposition involving the appointment of a small group of international legal experts with the authority to deliver discretionary judgments; the panels should, thus, be both inexpen- 
sive and operationally uncomplicated. Over time, individual panels might be incorporated into a single United Nations body, thereby offering an avenue to increased legitimacy, stability, investigatory reach and broader acceptance (Pogge 2008: 161-164).

As part of the structural support for democratic panels, an international democratic loan guarantee fund should also be formed. Such a fund would protect against the risk that future autocratic governments might retaliate against democratic panels by refusing to service the loans of previous democratic regimes - a risk that would make the countries in question a universal credit liability. If this retaliation occurred, the international democratic loan guarantee fund would step in with temporary capital for creditors; in this way, it would offer a permanent loan guarantee for creditors to democratic regimes. The capital would then need to be reimbursed when the country returned to democratic rule. And, of course, autocratic governments refusing to repay historical democratic loans would be held to have violated their international obligations while the same would not apply to democratic governments in the reverse situation. Autocratic governments would, thus, be punished by economic exclusion, sanctions and restrictions to future credit (Pogge 2008: 165-168).

\section{Addressing the Resource Privilege}

\section{"Democracy is a scalar predicate" - Thomas Pogge}

Mass atrocity crimes are statistically more likely to occur in situations of state collapse, loss of central authority, civil war, predatory takeover or political instability as well as under authoritarian rule (Ulfelder 2012; Bellamy 2011a: 97; Weiss 2007: 62). It is therefore important to address the role that the presence and seizure of natural resources often have in creating these circumstances. Statistics indicate that a typical country with 30-percent reliance on primary resource exports for its GDP is at a 33-percent increased risk of civil war, a risk that drops to 11 percent when resource reliance drops to 10 percent (Collier et al. 2003: 58). On the other hand, economies that are more than 25-percent reliant on the extraction of natural resources are five times more likely than their counterparts to experience periods of internal oppression and internal conflict (Goodhand 2001: 26-27).

In a 2005 report, the UNSC recognised the causal link between the level of exploitation of natural resources within an economy and the inflow of light arms and weapons (United Nations 2006). This is important because the sheer presence of such high levels of arms in conflict-ridden and fragmented societies has been shown to increase the likelihood of political oppression, civil war and mass atrocities (Pogge 2005a: 64-65), as experienced on countless occasions in the post-Cold War period (Yanik 2006). This resource-related "pull factor" 
for mass violence and predatory takeovers is so marked that the survival rate of any democratic regime drops by one percentage point with every one percent increase in the country's resource base (Pogge 2010: 48). In fact, in 1998, a UN Secretary-General report on conflict and sustainable peace in relation to the "resource curse" found that the "exploitation of natural resources" represented a substantial impediment to peace, democracy and the protection of human rights (United Nations 2006).

By this measure, the "resource privilege" is an institutional feature of the international order which incentivises violent, repressive governments, autocratic rule, coups, civil wars and communal violence (all contexts linked to mass atrocity crimes). Based on this privilege, the government of any given country regardless of how it came to power or how its power is maintained - has rightful ownership over the country's resources and therefore the right to sell and profit from them, irrespective of what the revenue is used for. This effectively creates a situation where the natural resources of a country are a permanent enticement to commit violence - they are the legitimate spoils of war (Collier et al. 2003: 58; Pogge 2005a: 72). This is an institutional challenge that could be overcome by reforms including the expansion of democratic panels and the introduction of a global resources dividend and an ecological tax.

Expanded democratic panels would operate in much the same ways as the panels assembled to address the borrowing privilege. In this case, weak and/or new democratic states would produce constitutional provisions declaring that legal rights over national resources only exist if the government in question is demonstrably democratic. Third-party willingness to purchase resources from autocratic governments would likely fall away on the understanding that future democratic governments would invalidate any such purchase agreements and seek compensation, or where possible, reappropriation. The democratic (or undemocratic) nature of governments would be adjudicated by expanded democratic panels, re-augmented for this purpose. All this would, however, also present some challenges. The disincentive to purchase resources would likely have a significant impact on domestic procurement because of the state's ability to re-possess property within the national jurisdiction. On the international level, however, it might hold less force. Attempts at international reappropriation or compensation would hinge on legal debate and, where available, international pressure, with no easy option available. And even if the legal argument were won and pressure created, purchasing countries could still refuse to abide by their obligations. For simple reasons of jurisdictional control, resource panels might have less power than borrowing panels to deter anti-democratic behaviour and violent repression (Pogge 2008: 168-172).

One complementary measure that might neutralise the resource privilege is the creation of a global resources dividend. This dividend would be based on the understanding that all citizens own a rightful share of the natural resources of 
their country; as such, a dividend should be paid on all resource transactions and associated degradation, erosion or removal impacts. This dividend would then be applied to meet the basic needs of all citizens (such as medical care, nutrition, sanitation and education). In effect, this would mean that a percentage of the profit attached to all of the country's resources would be returned to its citizens. The dividend wouldn't interfere with the areas of eminent domain or national control or the use of resources. At the same time, it would need to be globally administered in order to encompass all resource transactions and limit the jurisdictional control issue associated with resource panels. Beyond satisfying the basic needs of global citizens, the capital raised through the dividend could be used to help fund humanitarian operations and support supranational structures (Pogge 2008: 202-222).

Some kind of minimal, decentralised sanction mechanism would also be needed to enable individual countries to punish states proven to be in violation of the dividend obligations. The minimal nature of these sanctions is important since they would exist merely to impose an economic burden on the country matching what would otherwise have been imposed by the dividend - that is, as a way to incentivise compliance rather than inflict additional punishment. As a starting point, it is feasible that if the large economies of the United States and the European Union took part, then their resource market shares would effectively create a critical mass, producing the momentum needed for global compliance (Pogge 2008: 214). The dividend itself would need to be administered through the UN, which would then supply funding to non-governmental organisations (NGOs), regional organisations, international institutions and, if practical, domestic governments to initiate poverty-relieving development (Pogge 2008: 212-218).

Criticisms of the global resource dividend plan tend to focus on claims that given the extreme wealth of resources in question, the dividend distribution would have little impact on poverty, even less impact on inequality and less effect still on coups and autocratic governance. One fundamental objection holds that the dividend would put an unduly heavy burden on the primary extraction of resources rather than on purchasing countries; as such, there are fears that dividend-related costs would be returned to developing countries through a correlative rise in the price of manufactured goods. Beyond this, critics note that since the dividend focuses on a single point of extraction, it would do very little to deter environmental damage, which often affects poorer societies disproportionately since they tend to lack the capacity to reverse or mitigate changes. On this basis, the dividend would only contribute to entrenching poverty, underdevelopment and state weakness and producing a social reality prone to mass atrocities (Hayward 2005: 317-322).

The creation of "ecological space" is an alternative approach that might prove helpful in this context. Ecological space focuses on the "command of resources," 
a measure of the global hectares of water and land required to produce and consume resources and dispose of related waste. This figure is calculated by subtracting exports from both domestic consumption and national imports; this becomes a measure of "ecological debt." Taxation would be applied to debts of this kind, thereby transferring the redistribution burden from the country in which the resources originated to the governments that benefit most from their extraction (Hayward 2005: 317-331).

\section{Development and the Millennium Development Goals (MDGs)}

"One of the great challenges of the new millennium is to ensure that all states are strong enough to meet the many challenges they face" - Kofi Annan

Environments characterised by poverty, economic stagnation and underdevelopment are linked in deep and complex ways to the incidence of communal violence and mass atrocity crimes. Myriad examples of these links can be found in conflict zones in Rwanda (Weiss - Collins 2000: 100), Sierra Leone (Bellamy 2011a: 107), Ethiopia (Ignatieff 1999: 16), Bangladesh (Bellamy 2011a: 98), El Salvador, Nicaragua and Guatemala (Weiss - Collins 2000: 72), among others. One study notes that "[a]round 85 percent of new civil wars are either the marginalized countries falling into conflict or post-conflict countries relapsing" (Collier et al. 2003: 186-187). The corollary of underdevelopment, "state weakness," is a key factor in the occurrence of mass atrocities and related violence (Ulfelder 2012). In 2002 alone, half of all the world's civil wars and humanitarian interventions happened in Africa - in Somalia, Angola, Rwanda, South Sudan, North Sudan, Liberia, Sierra Leone, the DRC, Uganda, Mozambique, South Africa, Chad, Kenya, Nigeria, the CAR, Ethiopia, Eritrea, Western Sahara, Burundi and Mali - within environments of extreme underdevelopment that had previously also blighted the continent with a disproportionately high number of coups and genocides (Adelman 2002: 9).

State weakness invariably means that the best intentions and actions of international aid and intervention agents are not sustained; instead, such efforts waste away and these societies tend to relapse into conflict (Ignatieff 1999: 106). In this regard, an International Commission on Intervention and State Sovereignty (ICISS) report on the doctrine of Responsibility to Protect highlights the Responsibility to Rebuild (R2Rebuild) as a key priority (ICISS 2001: 5:1-5:31). Another study of 52 countries over the period 1960-1999 found that any given developing country had a 17-percent chance of descending into civil war within a five-year period. These countries could reportedly have halved this risk by doubling their per capita income; a further one percent reduction in risk was correlated with each one percent increase in growth (Collier et al. 2003: 58). Successful development is the most statistically certain means of immu- 
nising a country against communal conflict and mass atrocities; this has been explained as a "financial cushion" (Collier et al. 2003: 122). Youth employment and opportunities are vital if internal conflict, civil war and mass atrocities are to be avoided (Collier et al. 2003: 62-63). Development, employment and social opportunities help to mitigate the impact of the nefarious external financing of civil wars and coups (Collier et al. 2003: 127-128).

In addition, economic development and wealth are strongly correlated with democratisation based on the precipitous development of a new middle class on the path to genuine political representation (Huntington 1984: 198-199); there are also clear links with decreasing rates of corruption and cronyism (Moyo 2010). Conversely, the links between underdevelopment and mass atrocities tend to become cyclical, with the average civil war creating a 15-percent loss in per capita income (Collier et al. 2003: 84). Such wars cost the equivalent of four times the annual GDP of the country in question (Moyo 2010), tend to cause development challenges to spread to neighbouring countries and create large diasporas, thereby crippling a country's ability to redevelop (Collier et al. 2003: 84-85). These causal links pose a challenge for those seeking to increase the political will to address mass atrocities, a problem that led the then UN Secretary General Kofi Annan to comment: "Every step taken towards reducing poverty and achieving broad-based economic growth is a step toward conflict prevention" (ICISS 2001: 3.19). On this understanding, the existence of 750 million global citizens living in extreme poverty (Jones 2001) is a serious challenge to efforts to increase political support for humanitarian interventions since it may create the perception that the problem of mass atrocities is intractable.

The entrenched and entrapping nature of both poverty and underdevelopment (Azariadis - Stachurski 2004; Sachs 2007; Sachs et al. 2004) has dictated overly simple policy commitments to "development aid" as a means to break this cycle. (This is based on the view that the absence of wealth can be fixed by the supply of wealth.) However, such development aid has not only been proven consistently to fail in practice (Cotter 1979; Ovaska 2003; Bovard 1986; Moyo 2010) but also tended to do further harm to the very people that it intends to help and deepen development challenges. In this respect, development aid has often fostered corruption, stifled local industry, distorted markets, pushed up inflation, lowered employment opportunities, sapped domestic savings, incentivised unrepresentative governments, disenfranchised populations, encouraged dependency and decreased productivity (Anderson 1998: 138-153; Appiah 2006: 170; Moyo 2010). Beyond this, aid flows have been shown in and of themselves to prolong mass atrocities and civil wars that were already underway (Anderson 1998: 137; Weiss 2007: 74-75; Weiss - Collins 2000: 106), incentivise and sustain autocratic rule (Collier et al. 2003: 72-73; Bellamy 2011a: 109) and encourage communal conflict, coups and societal oppression (Collier et al. 2003: 63; Moyo 2010). 
Despite these findings, Jeffrey Sachs argues that extreme poverty can be eradicated in 20 years at an annual cost of $\$ 150$ billion (Appiah 2006: 173). This highlights the importance of producing an alternative development agenda to the present aid-heavy model. Though the rhetoric often suggests otherwise, a key impediment to development is, as Pogge $(2005 ; 78)$ has suggested, the maintenance by rich countries of protectionist barriers that limit the market access of exports from poorer countries. In 1999, the United Nations Conference on Trade and Development (UNCTAD) forecast that the developing world could export its way to a further $\$ 700$ billion in wealth by 2005 if the developed world only did more to open its markets to global competition (Jordaan 2010: 246). Among the liberal economic reforms desperately needed in the developing world, particularly for the promotion of good governance, are the introduction of independent banking regulators and independent central/reserve banks; financial integration in the region; the development and expansion of securities markets (both domestic and regional) and the creation and enforcement of corporate governance standards; there may potentially also be a need for the development of monetary unions such as the proposed African Monetary Union (United Nations Economic Commission for Africa - Southern African Development Community 2009). The end goal of these reforms must be "reach[ing] threshold levels of capital [...] to enable these economies to establish a process of self-sustaining growth" (Sachs et al. 2004). In many ways, this was also the objective of the UN Millennium Development Goals (MDGs).

Pogge has focused particularly on the MDGs, and they certainly offer a useful framework, which, if refined and fulfilled, could reduce conflicts, civil wars and mass atrocities (Collier, et.al. 2003: 186-188). The UN Millennium Declaration (2000) signified a moment at which all $191 \mathrm{UN}$ member states committed to eight development goals, the most prominent of which was "to halve, by the year 2015, the proportion of the world's people whose income is less than one dollar a day and the proportion of people who suffer from hunger" (Pogge 2010: 57). However, the MDGs were riddled with problems from the time of their inception and this has also affected their implementation. The goals were fundamentally a wish list, with an emphasis on impoverished countries and their reduction of poverty and little to no focus on countries that are free from or have little poverty. In addition to this obfuscating focus, the founding principles of the MDGs allowed member states to dilute the stated goals by selectively defining recording mechanisms and backdating the denominators for poverty and, also in some cases, altering the denominators retroactively. This meant that an extra 165 million people were left to live in extreme poverty in 2015 than would otherwise have been the case had a more accurate measure been used (Pogge 2010: 59). The total impact of this revision alone was a reduction in the size of the population to be relieved from poverty between 1996 and 2015 from 50 percent down to 20 percent (Pogge 2010: 71). This "clever shifting of goalposts" 
(Pogge 2010: 71) undermined the MDGs through several deft moves: it defined poverty based on income rather than the more accurate and informative metric of "hunger"; it adopted the language of "proportion" rather than "number" to evaluate what constitutes a reduction by half; and it put the focus on achieving a quick statistical fix rather than an overall increase in standards of living (Pogge 2010: 58-71).

While they represent an improvement, the Sustainable Development Goals (SDGs) which have replaced the MDGs, remain a wish list which lacks any real detail - Pogge (2015a), thus, calls them a "cosmetic effort." According to Pogge, improvements should be made by: i) describing and clarifying the specific responsibilities of capable states, international organisations and multinational enterprises; ii) appointing independent monitors to analyse failures and progress and specify the measurement methods and definitions that will be locked in for the 15-year life of the SDGs; iii) highlighting systemic/structural challenges such as democratisation, illicit financial flows and illicit arms flows and the need to prevent tax evasion, cancel unserviceable debts and avoid aid-based approaches; iv) making the SDGs part of a binding treaty rather than a voluntary agreement in order to stop states from skimping on their commitments; v) including robust human rights terms such as "interdependence," "indivisibility" and "universality" to improve the moral foundation and potential reach of the SDGs; vi) moving beyond an income-based measure of poverty to include overlooked factors such as illiteracy, undernourishment, child labour, exposure to violence and access to safe drinking water, electricity, essential medicines and sanitation and vii) focusing on inequality and not only poverty (Pogge - Sengupta 2014; Pogge 2015a).

\section{The Health Impact Fund}

"Poverty, when it is completely avoidable, is a massive crime against humanity" Thomas Pogge

Building on the causal links between poverty, state weakness and underdevelopment on the one hand and the occurrence of mass atrocity crimes on the other, it is important to address the specific health impact of such conditions. Eighteen million people die annually as a result of curable and/or treatable diseases that mostly occur within underdeveloped societies; this has the flow-on effects of social fragmentation and the loss of human capital, which in turn deepen poverty and block economic growth (Pogge 2008: 222). Outside of this, the lives of hundreds of millions of people are debilitated by the symptoms of avoidable diseases (Pogge 2008: 222), a situation with myriad negative effects including draining government resources, stripping away domestic savings (DSAED 2010; WHO 2014), damaging business opportunities, hindering educational outcomes, 
fracturing family structures, creating forced diasporas and reducing productivity (Acemoglu - Johnson - Robinson 2003: 398-401; Acemoglu - Johnson 2007).

Unhealthy people are often unable to work and under-perform when they are present at work. Similarly, sick children are less likely to attend school or to achieve high results when they do attend. It is also clear that reduced life expectancies in a society limit the strength of business arrangements and partnerships because of the increased likelihood of interruption by death. Against this, greater life expectancies lead to an increase in population size, and with it, GDP growth. Studies show that health is often the first index to improve on the path to economic development (Acemoglu - Johnson 2007; Acemoglu - Johnson Robinson 2003). The World Health Organisation (WHO) also acknowledges that improved health and access to essential medicines have a significant causal impact on "economic progress" (WHO 2014). Disease-ridden environments and poor health conditions within conflict situations work to exacerbate human suffering and have the long-term effect of perpetuating conflict-heavy situations (Gayer - Legros - Formenty - Connolly 2007).

These are conditions that produce mass atrocities and they are heavily contributed to by the extreme cost of, and sheer lack of research and development about, essential medicines for less developed societies (Chris - Singh - Sudarshi 2011; Pogge 2008: 222-261). Due to the high cost of pharmaceutical manufacturing, companies charge prices for their newly developed drugs that effectively put them out of reach of poorer communities. Alternatively, these companies simply focus on developing drugs that are targeted at richer societies, thereby obtaining greater profits but also ignoring the specific disease burdens of those most in need. Around the world today, 38 percent of all people lack access to essential medicines. To address this situation, Pogge suggests a new means of pharmaceutical development which could re-incentivise the industry to focus on the disease burdens in the developing world and so lift people out of violence-inducing poverty. This targeted approach involves the formation of a "health impact fund" (Hollis - Pogge 2008).

The production of new medicines is extremely expensive and risk-heavy in terms of research and development. For this reason, the World Trade Organization (WTO)'s agreement on Trade Related Aspects of Intellectual Property Rights (TRIPS) incentivises pharmaceutical development by offering long-term internationally enforceable patents amounting to a global market monopoly, thereby protecting the profitability of the industry. However, this agreement is part of the global institutional architecture that significantly harms already impoverished populations, who are unable to afford medications at current prices and also unable to develop their own generic copies. Additionally, the current system is weighted against medical research into the diseases and conditions that most commonly afflict impoverished and developing societies. While this medical research could have a far greater impact on human suffer- 
ing than research into the medical conditions associated with affluent societies, wealthier countries simply have a greater capacity to pay the high prices that must be charged in order to see a return on investments.

A health impact fund is an alternative payment system for medical development that would supplement the current system. This system would focus on medical progress in the developing world and deliver finished products at a marginal and affordable cost. Backed financially by willing governments, the fund would create an alternative incentive for socially conscious companies who would choose to focus on drugs for the developing world if only there were a profit to be made. The fund would do this by paying companies to forgo traditional patent options and be remunerated based on the calculable health impact of their medicines rather than traditional market factors. Opting into the fund would mean that all of the company's new medicines would be put on the market at marginal cost in order to make them as widely available as possible, thereby increasing each drug's achievable health impact (based on "quality adjusted life years"), and with it, the profits of the company responsible for its development. Though likely to be less profitable than the traditional patent system, the health impact fund would, thus, provide socially conscious companies with a platform through which to address the disease burden that so heavily afflicts the developing world while still pursuing a profit (Pogge 2008: 222-261; Pogge 2005b).

\section{Transparency}

"There is not a crime, there is not a dodge, there is not a trick, there is not a swindle, there is not a vice which does not live by secrecy" - Joseph Pulitzer

By simple virtue of achieving power, governments gain access to the benefits of international bribery and are protected in this access by the widespread nature and relative legitimacy of such behaviours. This system incentivises and rewards violent seizures of government by offering an easy avenue to material reward to anyone capable of holding power, regardless of the means. Such conditions, in turn, encourage cultures of self-interested rule as well as cultures of corruption that become normalised within a society. Indeed, before 1999 when relevant OECD legislation was introduced, such behaviours were generally considered legal, with many international firms being authorised by domestic governments to bribe foreign officials and able to receive tax deductions on such bribes (Pogge 2008: 29; Pogge 2010: 45-46).

Transparency is a key requirement for the implementation of institutional reforms, whether this involves changing entrenched values and behaviours, strengthening governments and regional and supranational organisations or securing funding and support for essential changes to protect against mass 
atrocity crimes. Transparency limits the allure of holding power by force as well as the pull factor for violent uprisings and the incentives for repressive rule (Pogge 2008: 212). Transparency within a society is strongly correlated with development outcomes: for every one- percent increase in a country's "opacity index," which signals a loss of transparency, there is an average one-percent decrease in Foreign Direct Investment (FDI) as a share of GDP along with a \$ 986 decrease in per capita income (Moyo 2010). Institutional transparency is widely considered to be the best solution to "financial volatility, environmental degradation, money laundering, and corruption" (Florini 1999).

A lack of transparency within international institutions remains the key barrier to achieving accountability within such institutions (Gartner 2013). The current level of transparency within organisations such as the WTO, the International Monetary Fund (IMF) and the World Bank remains disproportionately low given these institutions' global and domestic impact on conditions and policies (Reiterer 2009; Woods 2001). Moreover, transparency is a vital aspect of all successful economic functioning (Tuladhar 2005: 21-24) and it has cultural reach, having been shown historically to spread and become entrenched once a critical mass of political resistance can be overcome (Florini 1999).

The dominant supranational institutions, specifically the IMF, World Bank, UN and WTO, are architecturally archaic and yet their legitimacy remains paradigmatically linked to their accountability and decision-making processes. The secrecy of international institutions conceals the impact of their decisions and any malice or self-interest behind them (Woods 2001). The IMF and the World Bank do publish their decisions, but their decision-making processes are hidden. Similarly, the WTO allows access to all documents and minutes, however backstage deals and internal negotiation processes that produce specific legal language are still obscured from outside scrutiny, and this extends to sub-negotiations, panel proceedings and the full pleadings of the parties. It has, thus, traditionally been very difficult, if not impossible, to understand and deconstruct published documents or to determine which delegates argued for what, which countries insisted on which language and which language this excluded. Supranational organisations help design and control the global institutional order, but in reality this order is achieved through the lobbying of states and their representatives to influence the policy agenda - and those agents are granted anonymity around their behaviour (Steger 2008; Pogge 2011c).

In this sense, increased transparency and the opening up of decision-making processes at all levels of negotiations are often more important than greater/ wider participation at the supranational level. Key reforms would cover the thorough and immediate reporting of meeting minutes, including details of who is responsible for what language; the streamlining of ministerial conferences; the deeper and more open incorporation of NGOs in decision-making processes and the creation of institutional architecture to govern both initial 
and intermediary stages of the decision-making process including the creation/ implementation of a parliamentary dimension. Such steps would also promote institutional effectiveness, efficiency and successful outcomes (Spiro 1995; Wolfe 2005; Steger 2009).

A lack of international transparency - as enabled by corporate opacity, secret jurisdictions and tax havens - leads to the ability to launder money and create flows of illicit funding that finance terrorism, trafficking, light weapons sales, coups and civil wars, while also hindering development and democracy. Between $\$ 21$ and \$ 32 trillion in illicit, privately acquired financial wealth is currently held in secret jurisdictions, and the existing global environment is such that a global industry has formed to facilitate this behaviour with banks, corporations, accountancy firms and lawyers all competing for services. This normative legitimacy has created a situation in which as little as one percent of all illicit funds are detected globally (Pogge 2015b).

To address these problems, Pogge has proposed a number of systemic reforms including i) abolishing the legal right to form a shell company and so shedding greater light on the individuals and smaller companies that actually own and ultimately benefit from companies (in this regard, the G20 has adopted "Beneficial Ownership Principles" and the EU has forced member states to register companies so they can be accessed by law enforcement agencies; these rules, however, have limited reach and lack global influence); ii) abolishing the use of "anonymous accounts"; iii) developing a system that allows for the instant worldwide exchange of tax information; iv) requiring multinational corporations to report publically on all profits, sales and tax outlays for each and every jurisdiction that they do business or exist in (i.e. country-by-country reporting as a part of annual audits) and $v$ ) focusing on exposing the full responsibilities and complicity of powerful and rich actors and secret international jurisdictions and tax havens. Small nations such as the Cayman Islands, the Virgin Islands, Singapore, Hong Kong, Macau, Dubai, Switzerland, Luxembourg, Lebanon and Panama are unlikely to undertake transparency reforms unless countries such as the US and Germany lead the way (Pogge 2015b).

\section{Addressing the Banking Privilege and Tax Avoidance}

"The mistake you make, don't you see, is in thinking one can live in a corrupt society without being corrupt oneself" - George Orwell

The "banking privilege" works to incentivise violent uprisings, coups and repressive authoritarian rule by empowering governments and associated elites to misappropriate public funds through international bank accounts. The annual total cost of such embezzled funds, often flowing from less developed countries into more affluent countries, is estimated at \$ 1 trillion (Pogge 2010: 36). The 
international banking system facilitates the embezzlement of such public funds due to the benefit that they afford in terms of capital leverage (Pogge 2010: 50). Guinea is a particularly egregious example of the banking privilege in practice with the country's immense oil wealth largely being stolen by government and elites while 77 percent of the population still live below the poverty line under the autocratic rule of President Obiang. All this is despite the fact that the country's oil exports give it one of the world's highest per capita incomes ( $\$ 35,000)$. The transfer of these revenues to overseas banks has allowed the President's eldest son to purchase a $\$ 180$ million mansion in Paris and a $\$ 30$ million mansion in California, among other things (South African Foreign Policy Initiative 2013).

Similarly, developing countries lose $\$ 160$ billion annually in tax revenues alone (nearly $\$ 2.5$ trillion over the life of the MDG period 2000-2015), an amount which, if invested in health services, would be enough to save the lives of 350,000 children under the age of five every year. From the practice of misinvoicing alone, multinational corporations shift funds into outside jurisdictions at a rate of $\$ 760$ billion a year (the 2011 estimate of the Global Financial Integrity think-tank). This amounts to five to six times the total of all international development assistance that flows into developing countries each year. Thirty-three percent of all wealth privately owned by individuals in the Middle East and Africa and 26 percent of all individual wealth from Latin America is held outside the country of origin (Pogge 2014). The inability to collect tax on these funds restricts a country's ability to develop, build an engaged civil society and transition to/strengthen democratic institutions, all of which has a precipitous effect on the incidence of mass atrocity crimes. Tax abuse is often funnelled through the following methods though it is certainly not limited to these practices: (i) mispricing in order to shift corporate profits; (ii) intense lobbying by well-connected business groups for favourable tax treatment; (iii) the use of secret jurisdictions and tax havens and (iv) corrupt and illegal natural resource licensing (Pogge - Brock 2014).

There are various ways to impose global opportunity costs with respect to these challenges. At their core, these strategies involve targeting the responsible agents (the beneficial owners) and their behaviours and forcing them into the public spotlight. The agenda presented by Pogge includes: i) requiring all domestic governments to disclose the beneficial ownership of companies within their jurisdiction; ii) creating a publicly accessible, country-by-country tax and profit database for all multinational corporations; iii) creating a system for the automatic exchange of financial information; iv) establishing a mandatory international public database of all natural resource extraction, including details of related funds paid to governments and the subsequent use of that revenue by the government in question; v) standardising anti-money laundering regulations; vi) setting up a tough international legal structure, including significant 
penalties for the facilitators of illicit financial flows such as insurance agencies, legal firms, banks, accountancy firms and hedge funds; vii) mandating timely, frequent and public reporting of government fiscal policy and finances, as supervised by third parties and viii) renewing the global focus and engaging civil society in a discussion of the moral issues around tax evasion, tax bases, tax exempt status, tax gradients, uses of natural resources, tax reform policies, uses of tax revenue and the challenges of tax abuse (Pogge 2014; Pogge 2015b; Pogge - Sengupta 2014; Pogge - Brock 2014).

*** Ideally the above policy reforms and targets would be codified under a significant supranational accord such as the SDGs.

\section{The United Nations}

"Endorsing moral ideals is one thing, having real existing institutions that effectively protect them is quite another" - Roland Pierik and Wouter Werner

A 2001 ICISS report on the doctrine of the Responsibility to Protect stated that "the Commission is in absolutely no doubt that there is no better or more appropriate body than the Security Council to deal with military intervention issues for human protection purposes" (ICISS 2001: 6:14). This was in part an expression of a fear outlined by Kofi Annan: "If the conscience of humanity [...] cannot find in the United Nations its greatest tribune, there is a grave danger that it will look elsewhere for peace and justice" (ICISS 2001: 6.22). And yet, the United Nations Security Council (UNSC) was designed with a susceptibility to paralysis given the creation of veto powers for the Permanent Five (P5) Security Council members (Tsagourias 2013: 143) and it has operated in this manner ever since - a situation that has become a key impediment to attempts at humanitarian intervention (Pogge 2010: 167).

As such, much academic attention has been applied to United Nations reform, focusing particularly on the UNSC mechanisms. Proposed changes include democratising the UN; creating a P5 code of conduct (ICISS 2001: 6:21); establishing a UN constitution; expanding the General Assembly (UNGA) powers (ICISS 2001: 6:29, 6:30); expanding UNSC membership and limiting the veto power or abolishing it altogether. Such reforms would undoubtedly offer benefits, however they are unlikely to be adopted due to the absence of any subtlety in their challenge to the UNSC's authority. More intelligently targeted and conceptually focused reforms are required that will clear the hurdle of acceptance while still having a meaningful impact and helping operationalise the UN's stated values (Tsagourias 2013: 135-153). The need for UN reforms affects a range of key issues that could have a significant impact on mass atrocity crimes. These areas of action include regulating a responsible approach to global arms sales (Williamson 1998: 251-268); targeting rebels' external financing (Collier, et al. 
2003: 140-150); sharpening the focus of diplomatic pressure, embargoes and sanctions and, in particular, easing the political barriers to humanitarian intervention.

Proposals for reforms of just this kind have long been considered. A good example is the creation of a UN Standing Army that would ease concerns about dependency on powerful nations, be quickly deployable, remove the problem of differing interpretations of resolutions, serve as a symbolic and empowered global police force and enable smoother transitions to war crime prosecutions at the International Criminal Court (ICC) and Criminal Tribunals (Pattison 2008; Tsagourias 2013; ICISS 2001: 7:1-7:51). The 2001 ICISS report also proposed creating a P5 "Code of Conduct" in order to reform the UNSC. This was effectively recognition that though conceived with the best intentions, the R2P was limited by the whims of $\mathrm{P} 5$ members. The ICISS proposal essentially involved getting $\mathrm{P} 5$ members to refrain from using their veto powers over majority resolutions in cases where the particular P5 member's national interest was not the direct subject matter. Importantly, it also required the P5 to "constructively abstain" rather than veto otherwise majority humanitarian decisions (ICISS 2001: 6:21). Subsequent reform attempts have aimed to "democratise" the UNSC by increasing the decision-making capacity of the UNGA or imposing a UN constitution. Such a constitution would be a step towards creating confidence in both the behaviours and intentions of the member states. The text would definitively outline not only the rules, tools and structures of the UN but also importantly, a "common mindset," that is, a shared understanding of what constitutes peace and security (Tsagourias 2013: 151-152). To date, all these reform proposals have failed to gain any traction, partly because they entail a fundamental reconstruction of the UN.

By comparison, the "jurying process" developed by Thomas Franck targets the UN's overly "strict constraints" and their impact on international society. Similar to a grand jury but comprised of state representatives, this process provides an open forum for debating how law and moral norms should be applied in certain contentious situations. As a forum for debate that challenges international developments, the jurying process would be a means of reconciling common sense moral values with international law under an umbrella that gave them both equal weight. In this way, it should work to bypass dogmatic legal and institutional restrictions. The risk would, however, be that this process might be hindered by its own lack of impartiality and independence. Moreover, it would probablysuffer (though to a lesser extent) from the same political intransigence and strategic pressure from powerful states that plague the UNSC today (Pogge 2010: 165-177).

An alternative to this suggestion is the international court proposed by Pogge. This is envisaged as an "effective judicial organ for the authoritative interpretation and adjudication of international law - in real time" (Pogge 2010: 
180) - something which is currently absent from the international stage. This court would comprise a selection of independent judges with expertise in international law and UN procedure, and its role would be to deliver verdicts on - and provide clarity around - issues affected by UN power structures. Importantly, the creation of the court would be fairly non-intrusive but it would be capable of disproportionately influencing the behaviour of powerful states downstream.

The international court would effectively free the processes of defining and deliberating on breaches of international laws/conventions from the control and influence of powerful member states. As such, it would likely offer smoother and clearer legal and moral pathways to taking military interventions against mass atrocities. The court's independent nature would limit misuses of the law, thereby building a more vigorous international legal structure and likely triggering member states to launch long-delayed institutional reforms once it became clear that only the court could interpret and validate the UN's structural operations and aspects of international law. Unless a specific intervention was already forbidden under a UNSC declaration or by a UNGA supermajority, the court would have the legal and normative authority to make rulings authorising humanitarian intervention. This would be an important shift since by putting the emphasis on the passing of a "forbidding resolution" rather than an "authorising resolution," the court would largely remove the veto as a crippling barrier (Pogge 2010: 180-181).

The court's operations would need to be restricted by three precautionary principles: i) the court's legal justifications would have to be published in detail, with background deliberations also being made public; ii) court decisions could be overturned by the UNSC or a UNGA supermajority based on the court's perceived failings or substantial doubts concerning a decision and iii) court decisions could be overturned by the UNSC or a UNGA supermajority on the grounds that a legally approved intervention was operationally unfeasible and/or an unacceptable risk to human life and the international order (Pogge 2010: 181).

The most important feature of the court would, however, be its absolute commitment to independence and impartiality. The international court would need to resist all pressure to install channels by which states could exert influence, lest it lose its raison d'être and become a meaningless institutional structure. Together with a proven legal structure, this independence and impartiality should encourage early stage compliance. Furthermore, with the rise of China along with other potential world powers, the current upper echelon of states should be more willing to give international law a greater role in defining the global order and global operations than is currently the case. As such, the court has a growing chance of future implementation as global power dynamics shift and the world is confronted by new dominant powers while existing dominant powers search for a means of mitigation (Pogge 2010: 182). 


\section{Conclusion}

"Whatever we, as prospective participants unaware of our specific features, would desire society to be like is what, morally speaking, we ought to institute" -

Thomas Pogge

Due to an absence of political will to take action, the R2P, like other humanitarian interventions before it, has been a near total failure both institutionally and practically. The political, material and human costs associated with intervention have become near permanent barriers to fulfilling our moral obligations around mass atrocities. There is, thus, a need for reforms of the current institutional environment that have the capacity to reduce the material barriers for motivated states. These reforms should work to limit the prevalence, intensity and duration of mass atrocities and the crisis situations that make them possible, thereby reducing the various costs associated with any future intervention.

Through the predominantly poverty-focused work of cosmopolitan philosopher Thomas Pogge, and attention to key indices - for example, poverty, inequality, development, environmental degradation, natural resource extraction, autocratic governance, global health, ethnic tensions, arms flows, internal repression, democracy, transparency, United Nations operations and global tax evasion - precisely such a reform agenda is possible. Importantly, this is an agenda that is not so upfront and imposing as to clearly damage its chances of implementation, and yet it is also capable of having a dramatic impact on incidences of mass atrocities around the world.

\section{References}

Acemoglu, D. - Johnson, S. (2007): Disease and Development: The Effect of Life Expectancy on Economic Growth. Journal of Political Economy 115(6): 925-985

Acemoglu, D. - Johnson, S. - Robinson, J. (2003): Disease and Development in Historical Perspective. Journal of the European Economic Association 1(2-3):397- 405

Adelman, H. (2002): Theory and Humanitarian Intervention, in Keren, M. - Sylvan, D.A., eds, International Intervention: Sovereignty versus Responsibility. Frank Cass Publishing: Cornwall.

Anderson, M.B. (1998):You Save My Life Today, But for What Tomorrow?: Some Moral Dilemmas of Humanitarian Aid, in Moore, J., ed, Hard Choices: Moral Dilemmas in Humanitarian Intervention. Rowman \& Littlefield Publishers, Inc.: Maryland, USA.

Appiah, K.A. (2006): Cosmopolitanism: Ethics in a World of Strangers. Norton Publishing: New York. Azariadis, C. - Stachurski, J. (2004): Poverty Traps. Research Paper no. 913, Department of Economics, University of Melbourne. Prepared for Aghion, P. - Durlauf, S., eds), Handbook of Economic Growth. The University of Melbourne. 
Bellamy, A.J. (2011a): Global Politics and the Responsibility to Protect: From Words to Deeds. Routledge: New York.

Bellamy, A.J. (2011b): Mass Atrocities and Armed Conflict: Links, Distinctions, and Implications for the Responsibility to Prevent. Policy Analysis Brief. The Stanley Foundation: Iowa.

Bovard, J. (1986): The Continuing Failure of Foreign Aid. Cato Institute Policy Analysis no. 65: 1-15.

Chris, B. - Singh, S. - Sudarshi, D. (2011): Neglected Tropical Diseases, Conflict, and the Right to Health, in Institute of Medicine (US) Forum on Microbial Threats, The Causes and Impacts of Neglected Tropical and Zoonotic Diseases: Opportunities for Integrated Intervention Strategies. National Academies Press: Washington, D.C.

Collier, P. - Elliott, V.L. - Hegre, H. - Hoeffler, A. - Reynal-Querol, M. - Sambanis, N. (2003): Breaking the Conflict Trap: Civil War and Development Policy. The World Bank \& Oxford University Press: Washington, DC.

Cotter, W.R. (1979): How Aid Fails to Aid Africa. Foreign Policy 34 (Spring, 1979): 107-119.

De Simone, M. \& Fagan, C. (2014): Ending Secrecy to End Impunity: Tracing the Beneficial Owner. Transparency International. Policy Brief \# 02/2014.

Florini, A.M. (1999): Does the Invisible Hand Need a Transparent Glove? The Politics of Transparency. Carnegie Endowment for International Peace: Paper prepared for the Annual World Bank Conference on Development Economics, Washington, D.C., 28-30 April 1999.

Gartner, D. (2013): Uncovering Bretton Woods: Conditional Transparency, the World Bank, and the International Monetary Fund. The George Washington International Law Review (45): 121-148.

Gasiorowski, M.J. - Power, T.J. (1998): The Structural Determinants of Democratic Consolidation: Evidence from the Third World. Comparative Political Studies 31(6): 740-771.

Gayer, M. - Legros, D. - Formenty, P. - Connolly, M.A. (2007): Conflict and emerging infectious diseases. Perspective 13(11): 1625-1631.

Goodhand, J. (2001): Violent Conflict, Poverty and Chronic Poverty, CPRC Working Paper 6. INTRAC: 1-49.

Hayward, T. (2005): Thomas Pogge's Global Resources Dividend: A Critique and an Alternative. Journal of Moral Philosophy 2(3): 317-332.

Hollis, A. - Pogge, T. (2008): The Health Impact Fund: Making New Medicines Accessible for All, Incentives for Global Health. Incentives for Global Health (IGH), The World Health Organisation.

Huntington, S.P. (1984): Will More Countries Become Democratic?. Political Science Quarterly 99(2): 193-218.

Huntington, S. (1992): New Contingencies, Old Roles. Joint Forces Quarterly 2 (Autumn, 1992): 38-43.

International Commission on Intervention and State Sovereignty (ICISS) (2001): The Responsibility to Protect. International Development Research Centre: Canada.

Ignatieff, M. (1999): The Warrior's Honor: Ethnic War and the Modern Conscience. Vintage Publishing: Great Britain.

Jones, C. (2001): Global Justice: Defending Cosmopolitanism. Oxford University Press: Oxford, 
Jordaan, E. (2010): Questioning Thomas Pogge's Proposals to Eradicate Global Poverty. Global Society 24(2): 231-253.

Kuperman, A.J. (2001): The Limits of Humanitarian Intervention: Genocide in Rwanda. Brookings Institution Press: Washington, D.C.

Lea-Henry, J. (2014): A Poggean Approach to Mass Atrocities: Addressing Indeterminacy and Failures of Political Will for Humanitarian Intervention and the Responsibility to Protect. Deakin University: Melbourne.

Lijphart, A. (1991): Constitutional Choices for New Democracies. Journal of Democracy 2(1): $72-84$.

Moyo, D. (2010): Dead Aid: Why Aid Makes Things Worse and How There is Another Way for Africa. Penguin Books: London.

Ovaska, T. (2003): The Failure of Development Aid. Cato Journal 23(2): 175-188.

Pattison, J. (2008): Humanitarian Intervention and a Cosmopolitan UN Force. Journal of International Political Theory 4(1): 126-145.

Perkins, R. - Neumayer, E. (2008): Extra-territorial interventions in conflict spaces: Explaining the geographies of post-Cold War peacekeeping. Political Geography 27 (2008): 895-914.

Pinker, S. (2011): The Better Angels of Our Nature: Why Violence has Declined. Viking Penguin.

Pinkney, R. (2004): Democracy in the Third World. 2nd ed. Lynne Rienner Publishers: Colorado.

Pogge, T. (1989): Realizing Rawls. Cornell University Press: USA.

Pogge, T. (2002): World Poverty and Human Rights: Cosmopolitan Responsibilities and Reforms. Polity Press \& Blackwell Publishing.

Pogge, T. (2005a): Severe Poverty as Violation of Negative Duties. Ethics \& International Affairs 19(1): 55-83.

Pogge, T. (2005b): Human Rights and Global Health: A Research Program. Metaphilosophy 36 (1/2): 182-209

Pogge, T. (2008): World Poverty and Human Rights: Cosmopolitan Responsibilities and Reforms. 2nd ed. Polity Press: Cambridge.

Pogge, T. (2009): Baselines for Determining Harm, in Barry, C. - Rosenthal, J.H. eds, Ethics and international affairs: A reader. 3rd ed. Georgetown University Press: Washington.

Pogge, T. (2010): Politics as Usual: What Lies Behind the Pro-Poor Rhetoric. Polity Press: Cambridge.

Pogge, T. (2012a): Ending Poverty. RSA Keynote Lecture, 20 Nov 2012: available at http://www. thersa.org/events/audio-and-past-events/2012/ending-poverty (9 May 2014).

Pogge, T. (2012b): What Do Human Rights Demand From You and Me. Public Lecture Co-presented with the Institute for Democracy and Human Rights at the University of Sydney, 7 March 2012: available at http://sydney.edu.au/sydney_ideas/lectures/2012/professor_thomas_pogge.shtml (9 May 2014).

Pogge, T. (2014): Message to the UN: stop the loss of trillions of dollars to tax abuse. The Guardian: available at - https://www.theguardian.com/global-development-professionals-network/2014/sep/10/tax-avoidance-development-foreign-aid-united-nations (10 September 2014) 
Pogge, T. (2015a): Thomas Pogge Interview: 3 Ways to Improve SDGs. KAP talks lecture in Bucharest: available at - http://thomaspogge.com/thomas-pogge/poverty/thomas-pogge-interview-3-ways-to-improve-sdgs/

Pogge, T. (2015b): Thomas Pogge: How Are Human Rights and Financial Transparency Connected? Global Financial Integrity. Speech delivered at the University of Johannesburg, South Africa, 18 May 2015.

Pogge, T. - Brock, G. (2014): Global Tax Justice and Global Justice. Moral Philosophy and Politics 1(1): 1-15.

Pogge, T. - Sengupta, M. (2014): Sustainable Development Goals: A Better Pact is Possible!. Academics Stand Against Poverty.

Reiterer, M. (2009): The Doha development agenda of the WTO: Possible institutional implications. Progress in Development Studies 9(4): 359-75

Russett, B. - Layne, C. - Spiro, D.E. - Doyle, M.W. (1995): The Democratic Peace. International Security 19(4): 164-184.

Sachs, J. (2007): Breaking the Poverty Trap: Targeted investments can trump a region's geographic disadvantages. Scientific American (September 2007): 40-41.

Sachs, J.D. - McArthur, J.W. - Schmidt-Traub, G. - Kruk, M. - Bahadur, C. - Faye, M. - McCord, G. (2004): Ending Africa's Poverty Trap. Brookings Papers on Economic Activity March 2004 (1).

South African Foreign Policy Initiative (SAFPI) (2013): Is there an African resource curse? Open

Society Foundation For South Africa: available at: http://www.safpi.org/news/article/2013/ there-african-resource-curse (11 March 2014).

Spiro, P. J. (1995): New Global Communities: Nongovernmental Organizations in International Decision-Making Institutions. The Washington Quarterly (Winter 1995): 45-56.

Steger, D.P. (2008): Introduction to the Mini-Symposium on Transparency in the WTO. Journal of International Economic Law 11(4): 705-715.

Tsagourias, N. (2013): Cosmopolitan Legitimacy and UN Collective Security, in Pierik, R. - Werner, E., eds. Cosmopolitanism in Context: Perspectives from International Law and Political Theory. Cambridge University Press: Cambridg

Tuladhar, A. (2005): Governance Structures and Decision-Making Roles in Inflation Targeting Central Banks. International Monetary Fund (IMF) WP/05/183.

Ulfelder, J. (2012): Forecasting Onsets of Mass Killing. Paper presented at Northeast Political Methodology Meeting at New York University on 4 May 2012. The U.S. Holocaust Memorial Museum.

United Nations (2006): United Nations Expert Group Meeting on Natural Resources and Conflict in Africa: Transforming a Peace Liability into a Peace Asset. Organised by the Office of the Special Adviser on Africa (OSAA). Conference Report: Cairo, Egypt.

Weiss, T.G. (2007): Humanitarian Intervention: Ideas in Action. Polity Press: UK

Weiss, T.G. - Collins, C. (2000): Humanitarian Challenges \& Intervention. 2nd ed. Westview Press: Colorado. 
Williamson, R. (1998): Moving in Vicious Circles: The Moral Dilemmas of Arms Transfers and Weapons Manufacture, in Moore, J., ed. Hard Choices: Moral Dilemmas in Humanitarian Intervention. Rowman \& Littlefield Publishers, Inc.: Maryland, USA

Wolfe, R. (2005): Decision-Making and Transparency in the "Medieval" WTO: Does the Sutherland Report have the Right Prescription? Journal of International Economic Law 8(3): 631-645.

Woods, N. (2001): Making the IMF and the World Bank More Accountable. International Affairs 77(1): 83-100.

Yanik, L.K. (2006): Guns and human rights: Major Powers, global arms transfers, and Human rights violations. Human Rights Quarterly (28): 357-388.

Jed Lea-Henry is an Australian-born academic. After graduating from La Trobe University with majors in Political Science and Philosophy, Jed completed his post-graduate education in International Relations at Deakin University. His research has covered a broad range of topics, including humanitarian intervention, civil conflict, violence prevention, regional development and moral philosophy. Jed is currently an assistant professor in the Humanities and Social Sciences Faculty at Vignan University. You can follow his work or contact him directly at http://www.jedleahenry. org/.E-mail:jedlea_sh@vignanuniversity.org 